\title{
Development of a Bus Stop Design Guideline: Case Study on the Main Campus of Universiti Sains Malaysia (USM)
}

\author{
Mohamad Omar bin Bidin ${ }^{1}$, Mohd Alif Ikrami bin Mutti², Hafeezur Rahmaan bin Mohd Yassin ${ }^{3}$ \\ ${ }^{1}$ School of the Arts, Universiti Sains Malaysia, 11800 Pulau Pinang, Malaysia \\ ${ }^{2}$ School of the Arts, Universiti Sains Malaysia, 11800 Pulau Pinang, Malaysia \\ ${ }^{3}$ School of the Arts, Universiti Sains Malaysia, 11800 Pulau Pinang, Malaysia \\ m_omar@usm.my (Mohamad Omar bin Bidin¹), aimutti27@gmail.com (Mohd Alif Ikrami bin Mutti²), hafeezur@usm.my \\ (Hafeezur Rahmaan bin MohdYassin ${ }^{3}$ )
}

\begin{abstract}
Non-conducive bus stop designs can cause various problems to passengers, bus drivers and other vehicles on the road. A preliminary survey has revealed that specific guidelines have yet to be established as a reference for bus stop designs - to cater for consumer needs - especially in Malaysian university campuses. This study was conducted to initiate the set up of a guideline for a bus stop design in a university campus that meets users' needs; such as to provide ease of access, adequate comfort and safety. This study was conducted via qualitative methods by using a case study approach in Universiti Sains Malaysia (USM). A total of 24 respondents from different groups were interviewed, while five bus stops were selected as sample studies. The findings show that there are currently various design problems which concerned a number of aspects; such accessibility, comfort, and safety. By referencing various design guidelines, as well as principles explained in the Universal Design Guidelines, a bus stop design proposal for use in university campuses was developed. The proposed guideline provides a general overview of the 13-component physical criteria of the bus stop which should be adhered to, in order to meet the needs of various users in the USM campus. This guideline may serve as a critical reference to designers, architects or developers in building better, user- oriented bus stops in the future.
\end{abstract}

Keywords Guideline, Bus Stop Design, Universiti Sains Malaysia (USM), Universal Design (UD).

\section{INTRODUCTION}

The aim of this study is to propose a design guideline for bus stops that are easy to access, comfortable and safe for passengers to use, easy for bus drivers to maneuver, and does not affect other road users on campus. Most public university campuses in Malaysia have their own internal bus network to facilitate campus residents in moving within the campus area. This service helps reduce on-campus private vehicle usage that tends to increase each year (Meng, et al, 2002). The increasing number of private vehicles operating within campus borders cause issues such as air pollution, lack of parking spaces and traffic congestion (Toor and Havlick, 2004; Balsas, 2003). The same issues also occur in university campuses around the world such as in the USA (Balsas,2003),

Europe (Rotaris and Danielis, 2014) and numerous university campuses in Asia (Zhang, Li, Zhao, and
Wang, 2014; Alisar, Maya, Isam and Cynthia, 2013). A survey conducted on public universities in Malaysia

(Khorasani and Zeyun, 2014; R. Hashim, et al, 2013) demonstrated the need to upgrade bus services in its campuses. This includes the improvement of bus stop designs to accommodate the increasing number of commuters (Yi Fu, 2014; Eboli and Mazzula, 2009 and 2007; Litman 2008). Based on previous studies, there is a high tendency among students to use personal vehicles beginning at their second year of study. Difficulty in accessing bus stops, being uncomfortable and feeling unsafe at bus stops - especially during night time - are some of the issues that causes this to occur (Mohd Alif, et al, 2016). These aspects are closely related to each design component of the bus stop; and therefore show that design elements at bus stops play an important role in influencing the number of bus users incampus. 


\section{BUS STOP DESIGN}

According to the early planning model of bus stop design (Fernandez, 1999), there are two design aspects that need to be determined during the bus stop design planning stage; the components of the bus stop and its type. A total of 12 existing bus stop design guidelines have been analysed in order to identify the specification of bus stop designs in several countries that have used advanced systems of bus transportation such as the USA, England, Australia and Canada (Translink Transit Authority, 2012; SEPTA, 2012; TriMet, 2010; American Public Transportation Association(APTA),2010; WMATA,2009;

Translink, 2007; Transport for London, 2006; Darnell \& Associates, 2006; Roads Service, 2005; KimleyHorn \& Associates, 2004; The Florida Planning and Development Laboratory (TFPDL), 2003; TCRP, 1996). Table 1 shows the components and characteristics of each type of bus stop that have been identified.

Similar to other products and services, the overall design of a bus stop is comprised of various smaller components. Each component possesses its own design criterion which controls its size, shape and material. These criteria on the other hand, need to be welladapted to reflect the needs of a certain target user. As such, the development of a bus stop design guideline should specify clear requirements for each component of a bus stop in order to better address the needs of passangers, bus drivers and other road users.

\section{Table 1: The features and components for each type} of bus stop design.

\begin{tabular}{|c|c|c|}
\hline $\begin{array}{l}\text { Type of } \\
\text { bus stop }\end{array}$ & Criteria & Components \\
\hline $\begin{array}{l}\text { The } \\
\text { signage } \\
\text { bus stop }\end{array}$ & $\begin{array}{l}\text { Suitable for a bus } \\
\text { to droppassengers } \\
\text { only. }\end{array}$ & $\begin{array}{ll}\text { - } & \text { Signage } \\
\text { - } & \text { Platform }\end{array}$ \\
\hline $\begin{array}{l}\text { Common } \\
\text { /normal } \\
\text { bus stop }\end{array}$ & $\begin{array}{ll}\text { - } & \text { Usually used in } \\
\text { rural orsuburban. } \\
\text { - A small waiting } \\
\text { room capacity(less } \\
\text { than 6people). } \\
\text { - Bus stoptime } \\
\text { exceeds } 30 \\
\text { minutes. }\end{array}$ & $\begin{array}{ll}\text { - } & \text { Signage } \\
\text { - } & \text { Platform } \\
\text { - } & \text { Shelter } \\
\text { - } & \text { Seats }\end{array}$ \\
\hline $\begin{array}{l}\text { Medium- } \\
\text { sized bus } \\
\text { stop }\end{array}$ & $\begin{array}{l}\text { Commonly placed } \\
\text { in towns andcities, } \\
\text { university } \\
\text { campusesand } \\
\text { along main }\end{array}$ & $\begin{array}{ll}\text { - } & \text { Signage } \\
\text { - } & \text { Platfom } \\
\text { - } & \text { Information } \\
\text { board }\end{array}$ \\
\hline
\end{tabular}

Table 1, cont.

\begin{tabular}{|c|c|c|}
\hline & $\begin{array}{l}\text { routes/highways. } \\
\text { Has a medium- } \\
\text { sized capacity for } \\
\text { waitingpassengers } \\
\text { (less than 12pax). } \\
\text { - Time interval } \\
\text { between buses } \\
\text { generally under30 } \\
\text { minutes. }\end{array}$ & $\begin{array}{ll}\text { - } & \text { Shelter } \\
\text { - } & \text { Seats } \\
\text { - } & \text { Buszone } \\
\text { - } & \text { Lighting } \\
\text { - } & \text { Boarding } \\
& \text { and } \\
& \text { Alighting } \\
& \text { Pad(BAP) } \\
\text { - } & \text { Pedestrian } \\
& \text { walkway } \\
\end{array}$ \\
\hline $\begin{array}{l}\text { Premium } \\
\text { bus stop }\end{array}$ & $\begin{array}{l}\text { - Typically placedin } \\
\text { concentratedareas; } \\
\text { i.e. main routes } \\
\text { connecting } \\
\text { shopping districts } \\
\text { and hospitals in } \\
\text { large cities. } \\
\text { - Has a highcapacity } \\
\text { for waiting } \\
\text { passengers (over } \\
12 \text { pax). } \\
\text { Time interval } \\
\text { between buses } \\
\text { generally under12 } \\
\text { minutes. }\end{array}$ & 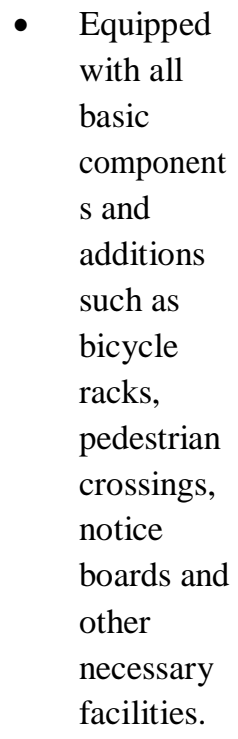 \\
\hline
\end{tabular}

\section{DESIGN GUIDELINES}

Within the design discipline, the process of creation takes place in a number of phases; starting with research and data collection, generating ideas and concepts through visuals or prototype models, assessment, production, launch and continuous observation (Martin and Hannington, 2012). Through research, issues and consumer needs are analysed to identify remedial steps that may be taken to improve the product or service. The results of the analysis are typically summarised into a list that contains the criteria required in a specific design. This list is also known as a design brief and is used by designers as a guideline in idea generation or concept development (Kasim, 2000). This guideline is critical in keeping the product's final outcome in line with its intial purpose; which is to solve a specific problem and fulfill the client (or consumer's)need.

However, preliminary research indicates that there is currently no guideline in existence for bus stop designs in Malaysia, especially for university campuses. Universal Design Guidelines that was laid down by the Town and Country Planning Department of Peninsular Malaysia (2011) only included general criteria concerning the adaptation of bus stops to accommipgate 
disabled users. Similarly, references from the Department of Standards Malaysia made no mention of any design recommendations which were specific for bus stops. This situation stands in contrast to other countries with well-developed public transport networks; such as the USA, England, Canada and Australia. Each transport service provider in those countries has guidelines of their own to standardize their bus stops (WMATA, 2009; Transit Cooperative Research Program (TCRP), 1996; Transport for London, 2006; Translink, 2007). Furthermore, according to Shuhana, et al., (2007), currently, consulting urban planners, architects and designers rely heavily on references originating from foreign countries for the purpose of designing Malaysian campus environments. Therefore a need is established for a locally-specific design guideline, to optimize our local resources and prevent wastage - stemming from weak design decisions - as well as to assist government agencies and developers in planning and building conducive and sustainable campuses in the future.

\section{UNIVERSAL DESIGN}

The Univeral Design (UD) approach is utilised in this research. UD is an approach in design that was based on a concept that each individual should have equal access to every sort of service at any time (Connet et al., 1997). This concept encompasses domestic design, workplaces, transportation, communication, digital devices, furniture and various services to assist users in their daily lives; regardless of their physical capabilities. According to Connel et al. (1997) and Story et al. (1998), in order for UD to be established, a team of designers, architects, enginners and researchers from various disciplines worked together to draft the seven principles. They are: (i) Equitable Use, (ii) Flexibility in Use, (iii) Simple and Intuitive Use, (iv) Perceptible Information, (v) Tolerance of Error (vi) Low Physical Effort, and (vii) Size and Space for Approach and Use. These principles are in line withthe concept of commuter bus services, especially when considering the provision of bus stops. Within the commuter bus network, bus stops are provided for the convenience of two groups of people; the passengers and the bus drivers. Passengers, both abled-bodied and disabled, use the same bus stop facility to wait for the buses to arrive, to board and also to descend the carriages. On the other hand, bus drivers utilise the bus stops to pick up and drop passengers off. However in the development of bus stop designs, opinions from other road users have to be included too; to avoid potential conflicts that may occur when buses pull over into the stops, possibly causing an obstruction in traffic that may lead to a larger scale congestion and delay in others' commute (Tyler,2006).
Apart from that, principles in UD are also suitable for use in the context of university campuses in Malaysia; where students, staff members and visitors consist of people from various levels of age and physical capabilities. In fact, UD has been used to form the basis of design for other services for various users, such as in playgrounds, car parks, restrooms, interior design or external building facilities and public transport terminals (Jabatan Landskap Negara, 2010; Town and Country Planning Department of Peninsular Malaysia, 2011; Nor Azlina,2016).

\section{METHODOLOGY}

This research utilised a qualitative methodology by using the 'case study' design approach (Yin, 2011). Data collection that involved numerous users was conducted around bus stop samples in the Universiti Sains Malaysia (USM) main campus. Overall, collection of data was completed in a number of phases, in reference of the Information Research model (Kasim, 2000) which explained the steps to establish design criteria in industrial design. The phases involved are described in Table2:

Table 2: Sources of information and data gathered for each research phase.

\begin{tabular}{|c|c|c|c|}
\hline Phase & $\begin{array}{c}\text { Data } \\
\text { collection } \\
\text { technique }\end{array}$ & Source & Data \\
\hline $\begin{array}{c}1 . \\
\text { Preliminary } \\
\text { research }\end{array}$ & $\begin{array}{l}\text { Literature } \\
\text { review }\end{array}$ & $\begin{array}{l}\text { Past research, } \\
\text { books, journal } \\
\text { articles, } \\
\text { documents }\end{array}$ & $\begin{array}{c}\text { Terms, } \\
\text { definitions, } \\
\text { keywords }\end{array}$ \\
\hline $\begin{array}{c}2 . \\
\text { Project } \\
\text { scope } \\
\text { definition }\end{array}$ & $\begin{array}{c}\text { Document } \\
\text { analysis }\end{array}$ & $\begin{array}{c}\text { Design } \\
\text { guideline for } \\
\text { existing bus } \\
\text { stops }\end{array}$ & $\begin{array}{c}\text { Types, } \\
\text { specifications } \\
\text { and } \\
\text { components of } \\
\text { bus stop design }\end{array}$ \\
\hline $\begin{array}{c}3 . \\
\text { User } \\
\text { feedback }\end{array}$ & $\begin{array}{c}\text { Focused } \\
\text { interviews }\end{array}$ & $\begin{array}{l}\text { Respondents: } \\
\text { Students, staff, } \\
\text { visiors, bus } \\
\text { drivers, private } \\
\text { vehicle } \\
\text { motorists }\end{array}$ & $\begin{array}{l}\text { Problem and } \\
\text { user needs } \\
\text { identification }\end{array}$ \\
\hline $\begin{array}{c}4 . \\
\text { Survey on } \\
\text { existing bus } \\
\text { stops }\end{array}$ & Observation & $\begin{array}{c}\text { Sampling: } 5 \\
\text { bus stop } \\
\text { samples in the } \\
\text { main campusof } \\
\text { USM }\end{array}$ & $\begin{array}{l}\text { Existing bus } \\
\text { stop design } \\
\text { problem } \\
\text { identification }\end{array}$ \\
\hline $\begin{array}{c}5 . \\
\text { Expert } \\
\text { advice }\end{array}$ & Interview & $\begin{array}{c}\text { Expert in } \\
\text { design, student } \\
\text { infrastructure } \\
\text { and transport } \\
\text { planning }\end{array}$ & $\begin{array}{c}\text { Verification of } \\
\text { data and } \\
\text { improvement } \\
\text { criteria }\end{array}$ \\
\hline
\end{tabular}




\section{DATA ANALYSIS}

Data triangulation was used in this study to discuss and compare data to form research findings. This analysis consists of a set of collected data from various samples and respondents to generate more concrete findings (Yin, 2011). Figure 1 shows how the triangulation analysis was utilised in this study.

Figure 1: Research analysis with data triangulation

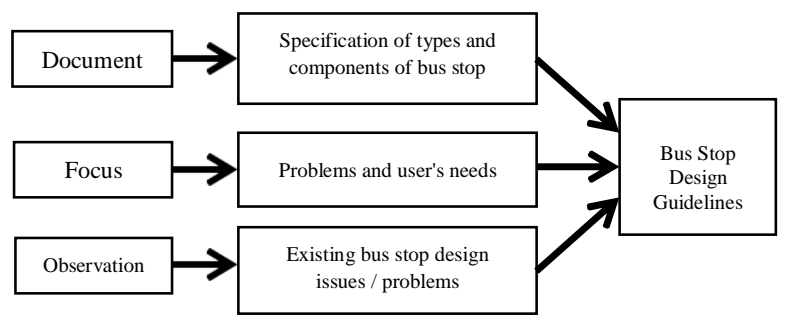

\section{FINDINGS}

\section{Bus stop design guidelines in USM campus}

Based on the high numbers of users, the frequency of bus routes and focal points within the research samples, this study recommends bus stop designs of a premium type, while retaining basic components such as was listed in Table 1, as well as a number of additional supporting facilities like waste bins, railings, pedestrian crossings and designated wheelchair zone. The design criteria for each of these recommended components are asfollows;

\section{i. Bus StopPlatforms}

Figure 2: Proposed criteria for bus stop platforms at bus stops in the USM main campus.

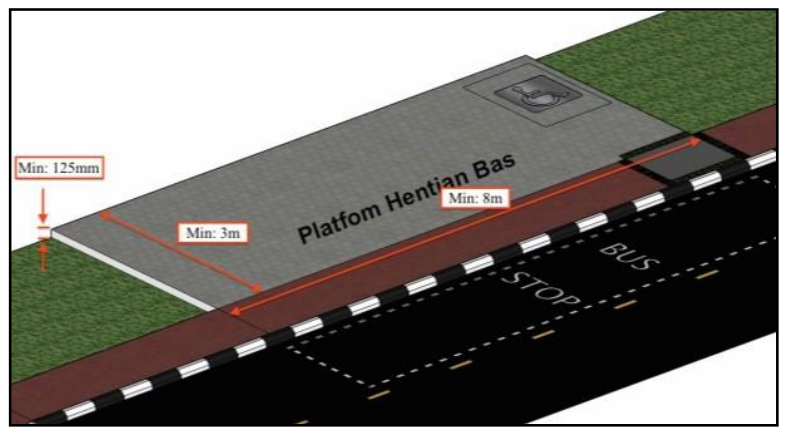

Design Criteria for Platforms

- Platform need to be built on a minimum area of $8 \mathrm{~m}$ long and $3 \mathrm{~m}$ wide. This area sizing can accommodate a disabled person and space for 15 seats on theplatform.

- The height of the platform from road level shouldbeequaltotheheightofthecurb which is at a minimum of $125 \mathrm{~mm}$ and 180 $\mathrm{mm}$ maximum. This size allows passengers to step in or out of the platform easily andsafely.

- The surface of the platform should be paved, have anti-slip properties, is easy to clean and drains waterefficiently.

\section{ii. InformationDisplays}

Figure 3: Proposed criteria for information display at bus stops in the USM main campus.

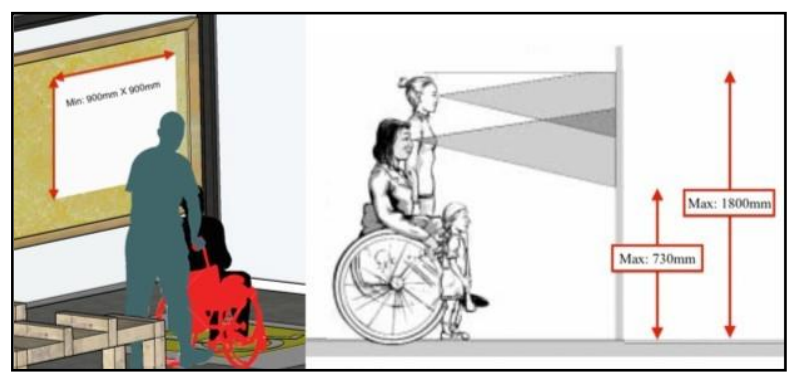

Design Criteria for Information Panels

- The minimum size for the panel should be $900 \mathrm{~mm}$ X $900 \mathrm{~mm}$, at a height of $1800 \mathrm{~mm}$ (top frame of the panel) and $730 \mathrm{~mm}$ (bottom frame of the panel). This size and positioning of the information panel allows able-bodied and wheelchair-bound users to read displayed informationclearly.

- Use of symbols and text should be easily read, clear, without use of the italic style and are not decorative in nature; so that users may understand the information displayed easily and effectively.

- Use of braille writing should be included for vision-impaired users.

- Displayed information should include estimated time of arrival for the buses, bus schedule, bus routes, bus route directions, location map within campus grounds and emergency callnumber. 


\section{iii. Bus StopSignboards}

Figure 4: Proposed criteria for bus stop signboards at bus stops in the USM main campus.

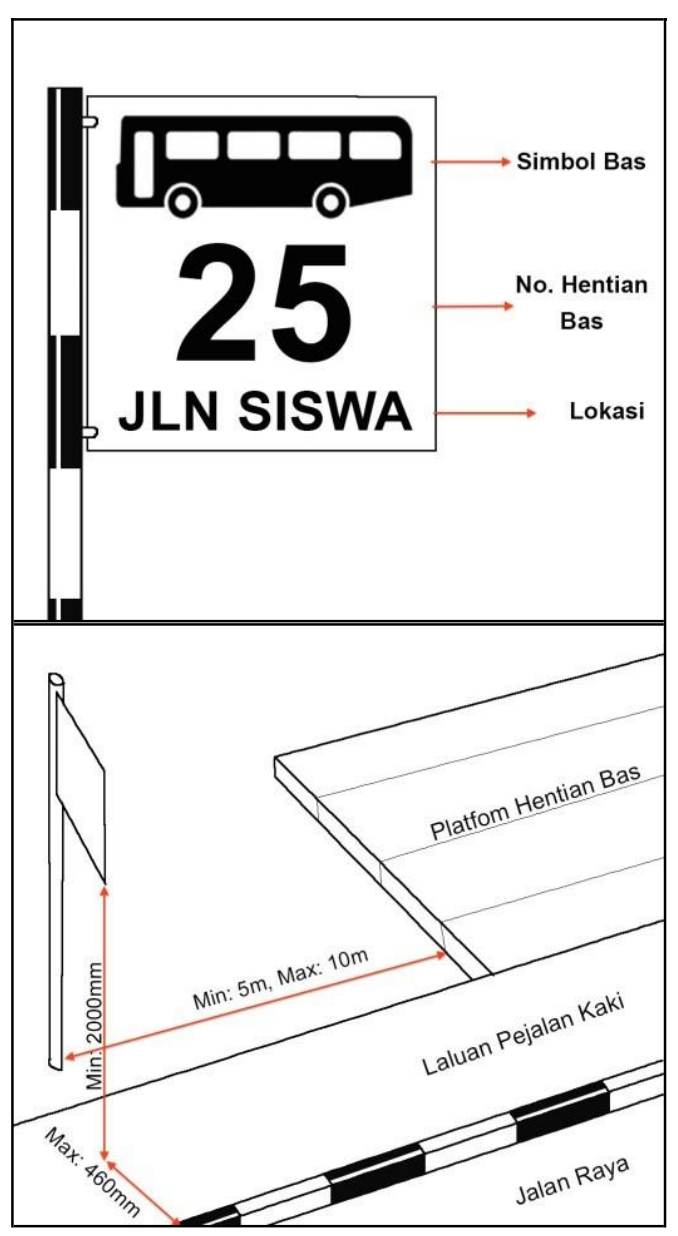

Design Criteria for Bus Stop Signboards

- Erected neatly at a minimum position of $5 \mathrm{~m}$ and maximum of $10 \mathrm{~m}$ before the bus stop. This position allows the public to read the information before overshooting the bus stop and so that precautionary steps can be taken prior to the arrival to the busstop.

- The bottom edge of the signboard should be at a height of $2032 \mathrm{~mm}$. This measurement allows pedestrians and wheelchair-bound users to cross beneath the signboard safely and comfortably without causing fatigue, injury and adoption of a non-neutralposture.

- Information on the signboard shoulddisplay the bus stop's number, name of the road/street and location; in the form of pictogram and fonts that are not italic, brief, and easy to read and understand. In addition to that, the texts and symbols should employ contrasting colours like white on blue, or yellow on black.

\section{iv. Bus Zones}

Figure 5: Proposed criteria for bus zones at bus stops in the USM main campus.

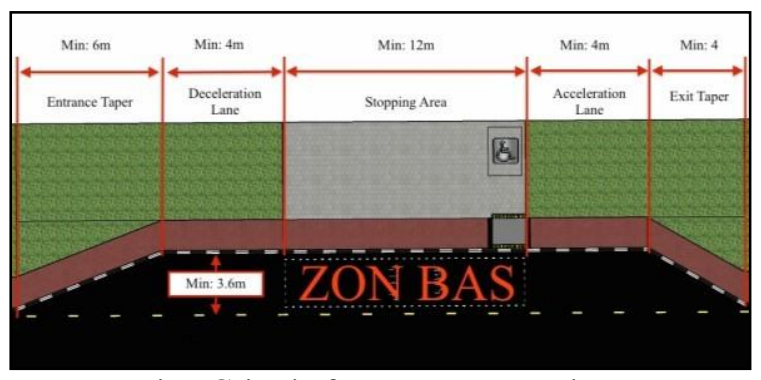

Design Criteria for Bus Zone Design

- Bus zone should be designed with a bus-bay at every bus stop within the campus; with capacity of a single bus at anytime.

- Surface markings should be provided for a bus at every bus zone. These markings act as warning for pedestrians and other motorists to keep their distance from the bus zone - to avoid from creating obstructions and potential incidents when buses approach the platform to pick up and drop offpassengers.

- The surface of the bus zone should have good water drainage to prevent water accumulation during rainy days and water-splashing at the approach of thebuses.

- The width of the bus zone is $3.6 \mathrm{~m}$ from the curb to the road surface. This size allows a bus to stop, pick up and drop off passengers without obstructingtraffic.

\section{v. BusShelters}

Figure 6: Proposed criteria of bus shelters at bus stops in the USM main campus.

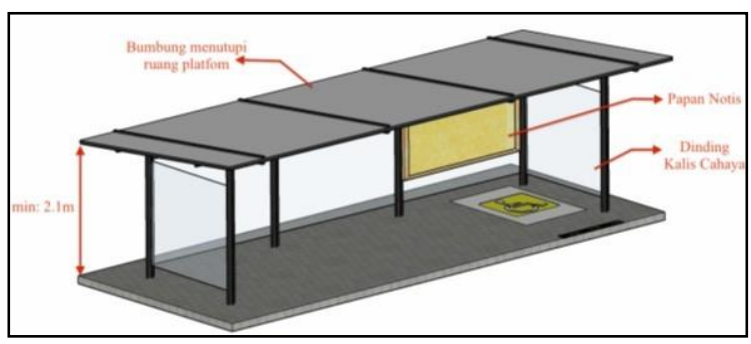

Design Criteria for Bus Shelters

- Bus shelters should be designed at a position that is facing the road, where the interior of the bus is visible to the public, as well as provide a line of vision between waiting passengers and the bus driver; reducing danger risks.

- The surface of the bus shelter roof should covertheentirestopataheightof $2.1 \mathrm{mfrom}$ 
the platform floor level. This height allows passengers to descend from the bus without having to lower their heads.

- Ventilation in the shelter should be adequate for the comfort of the users that are waiting for thebus.

- The shelter's walls should be present at the back and sides to prevent wind-swept rain that can cause discomfort tousers.

- Every bus shelter should provide a notice board to display information, advertisements and announcements.

\section{vi. Seats}

Figure 7: Proposed criteria for seats at bus stops in the USM main campus.

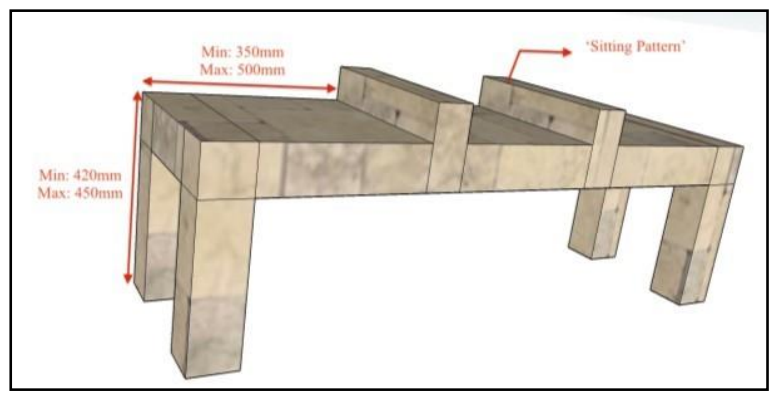

Design Criteria for Seats

- Seats should be placed within the bus shelter and not obstruct walkways or the wheelchair zone.

- The height of the seats from the platform floor level should be at a $420 \mathrm{~mm}$ minimum, and $450 \mathrm{~mm}$ maximum. On the other hand, the width of the seats should be $300 \mathrm{~mm}$ minimum, and 500mm maximum, following specifications that are used for public seats (Jabatan Landskap Negara,2010).

- Capacity of the seats should accommodate 15 people at any time, relating to the schedules and estimates of user capacity inUSM.

- The seating should be of bench-type, with a sitting pattern that functions to prevent users from sleeping on the facility, as well as restrict one seat to a singleuser.

- The seat should be built from a sturdy material that provides little risk ofbeing stolen orvandalised.

vii. Lighting at BusStops

\section{Design Criteria for Lighting}

- Lighting within the bus shelter should be provided with a 250 watt (maximum) metal halide lamp and/or a 150 watt (maximum) high pressure sodium lamp (Nain \& Murdoch, 1997).
- Lamps at the left and right sides of theshelter should be at a distance of $10 \mathrm{~m}$ from the middle point of the facility, as was recommended by Nain \& Murdoch(1997).

viii. Boarding and Alighting $\operatorname{Pad}(\mathrm{BAP})$

Figure 8: Proposed criteria for BAP at bus stops in the USM main campus.

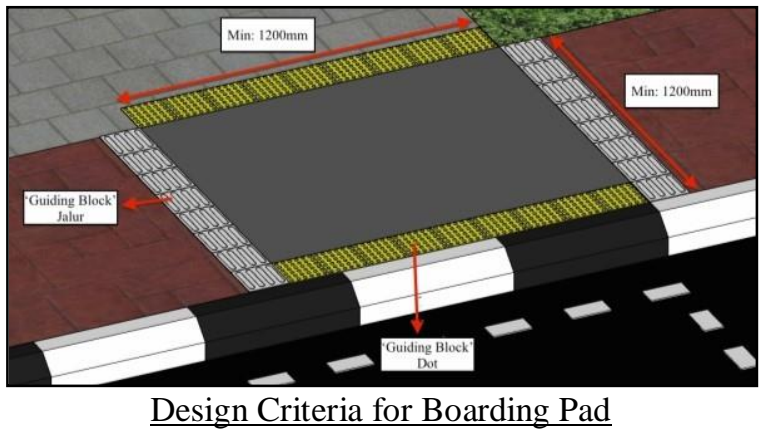

- The minimum width should be $1200 \mathrm{~mm}$ to accommodate access to a wheelchair-bound passenger, with clearance of $270 \mathrm{~mm}$ at each side.

- The surface of the floor should be level with the platform, with anti-slip properties and adequate waterdrainage.

- It should connect directly to the bus stop platform and pedestrian/wheelchair passageways without any physical obstructions such as stairs exceeding $25 \mathrm{~mm}$ - so as not to hinder unassisted wheelchair- bound passengers.

- The boarding pad should be installed with a lined guiding block that functions to indicate the entrance and exit of the bus stop to visionimpaired users. Dotted guiding blocks on the other hand should be installed at the edge of the boarding pad as cautionary indication. This criterion refers to the needs of vision- impaired users that require cues to navigate within the facilitiessafely.

ix. PedestrianWalkways

Figure 9: Proposed criteria for pedestrian walkways at bus stops in the USM main campus.

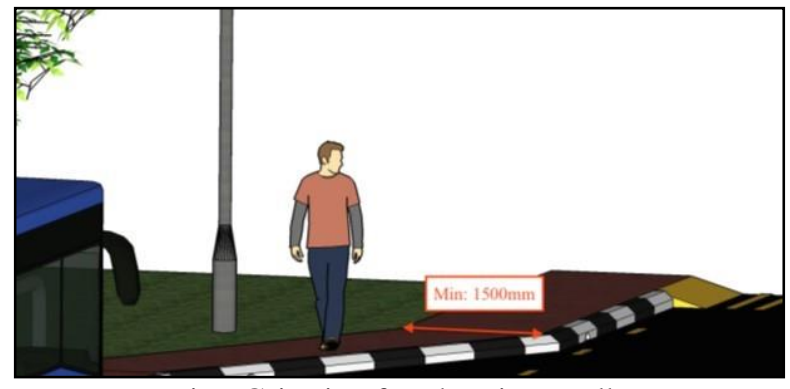

Design Criteria of Pedestrian Walkways 
- Minimum width of the walkways should be $1500 \mathrm{~mm}$ to accommodate wheelchair-bound users, as well as to allow clearance of $420 \mathrm{~mm}$ at each side, according to recommendations from the dalam Jabatan Landskap Negara (2010).

- The surface of the walkway floor should be level with the platform, with anti-slip properties. It should also be equipped with adequate drainage to allow passengers to access and exit the platform comfortably and safely.

- It should be connected directly to the bus stop platform without any physical obstructions, such as stairs exceeding $25 \mathrm{~mm}$ in height, so that wheelchair-bound passengers may cross withoutassistance.

\section{x. Waste Bins}

Placement Criteria of Waste Bins at Bus Stops

- Every waste bin at USM bus stops should be placed at a maximum distance of 1 meter from the platform, and a maximum of $350 \mathrm{~mm}$ from the pedestrian walkways. This is to ensure that the waste bins are close enough that rubbish can be discarded with minimal movement, without obstructing passage ofpedestrians.

\section{xi. Railings}

Figure 10: Proposed Criteria for railings at bus stops in the USM main campus.

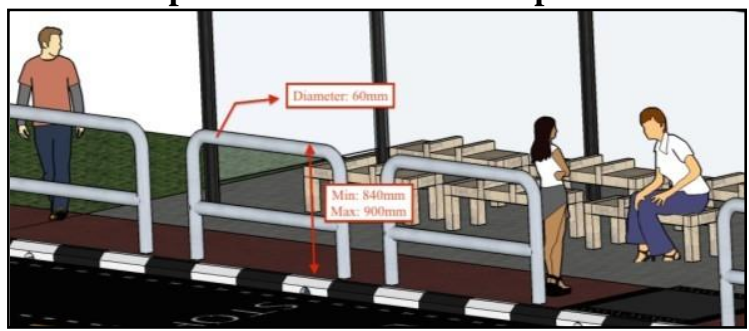

Design Criteria for Railings at Bus Stops

- Railings should be installed at bus stops in the USM main campus as barrier to areas with highrisk.

- Minimum height of the railings should be $840 \mathrm{~mm}$, and maximum, at $900 \mathrm{~mm}$. The circumference of the handrail on the other hand, should be $45 \mathrm{~mm}$ minimum, and $60 \mathrm{~mm}$ maximum. This recommended measurement is based on JBPDSM (2011) in the guideline for Universal Design Planning inMalaysia.

\section{xii. PedestrianCrossing}

\section{Design Criteria for Pedestrian Crossing}

- Pedestrian crossings should be placed at a maximum distance of 25 meters from the bus stop platform and connect directly to the walkway, as well as having ramps at every end of wheelchair access.

- They should be equipped with warning signposts at the roadside, close to the crossings, as well as yellow indication lines going across the road as warning for motorists and navigation guide forpedestrians.

- Lined guilding blocks should be installed to function as navigation cues for entry and exit from the bus stops, for vision-impaired users. Dotted guiding blocks on the other hand, should be installed at the end of the crossing as indication forcaution.

\section{xiii. WheelchairZone}

\section{Figure 11: Proposed Criteria for wheelchair zone at bus} stops in the USM main campus.

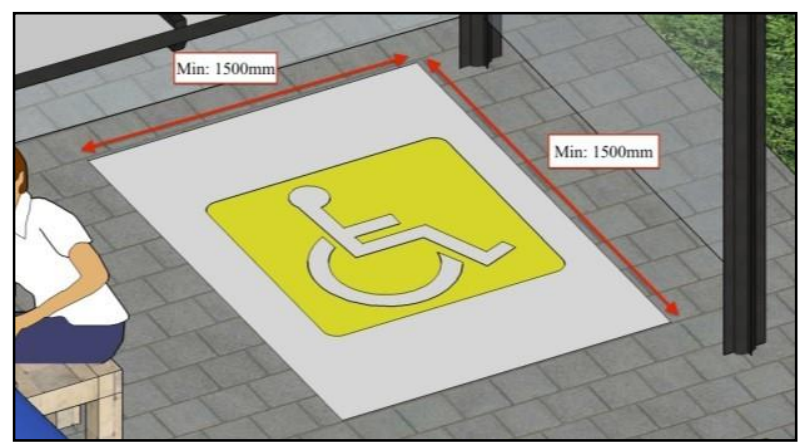

Design Criteria for Wheelchair Zone

- Minumum size of the wheelchair zone should be $1500 \mathrm{~mm}$ in length and $1500 \mathrm{~mm}$ in width; according to the minimum size for movement of wheelchair-bound passengers (inclusive of clearance area), (Jabatan Landskap Negara, 2010).

- The surface should be painted with a symbol or clear writing as indication of area designated for disabled/wheelchair-bound passengers.

- The wheelchair zone should be placed within the bus shelter, away from direct sunlight and rain.

- The surface of the floor should be level with the platform floor, to avoid potential injuries and to ease movement in/out of thezone. 


\section{CONCLUSION}

The design guideline proposed in this research encompasses general criteria which involved technical elements in design, such as size, material and form for each vital component of a bus stop. These criteria were established based on a combination of various sources of information in planning guidelines as well as reference to existing bus stop designs in a number of countries with matured bus networks. In terms of size, the dimensions used were based on the antrometrics of Malaysians (Darliana, et al, 2008), and specification of commuter bus types were based on that which are commissioned in the main campus of USM. One of the main functions that is focused on in the guideline is the ability for passengers and bus drivers to navigate into and out from the bus stops with ease, without physical obstructions. Apart from that, priority is also given to the aspects of comfort and safety of passengers while waiting at the bus stop, as well as when alighting and descending from the buses. Allocation for a larger space also allows buses to pull over at the bus stop without disrupting the flow of traffic in the campus. UD was utilised entirely in the development of this guideline in the fact that every criteria for each component mentioned are related to the principles of UD, whether it involved size, space, material or addition of facilities. The application of UD in the guideline allows bus stops to accommodate disabled users, while providing adequate comfort andsafety.

Validation of this research was proven via reference by an industry expert. However, its effectiveness has yet to be tested on a practical scale. This recommended guideline will have to be further developed into a detailed design concept, so as to be utilized by users. Therefore, it falls on to designers and the campus development team to improve bus stops according to this guideline, so that the research may be fully tested, and for further improvements to be made and implemented.

\section{REFERENCES}

[1] Alisar, A., Maya Abou-Zeid, Isam K.,Cynthia, M. (2013), Reducing parking demand and traffic congesting at the American University of Beirut. Transport Policy 25, pg. 52-60.
[2] Balsas, C. J. L. (2003), Sustainable and transportation planning on college campuses. Transport Policy 10, pg. 35-49

[3] Connel, B. R., Jones, M., Mace, R., Mueller, J., Mullick, A., Ostroff, E., Sanford, J., Steinfeld, E., Story, M. \& Vanderheiden, G. (1997). The principal of universal design, North Carolina State University: The Center for Universal Design.

[4] Eboli, L., dan Mazulla, G. (2009), A New Customer Satisfaction Index for Evaluating Transit Service Quality. Journal of Public Transportation, 12 (3), pg.21-37.

[5] Eboli, L., dan Mazzulla, G. (2007). Service quality attributes affecting customer satisfaction for bus transit. Journal of Public Transportation, 10(3), pg. 21-34.

[6] Fernandez R., (1999). Design of bus stop priorities. Traffic Engineering and Control 40 (6), pg.335-340.

[7] Jabatan Landskap Negara (2010), Panduan Reka Bentuk Sejagat (Universal Design) Kemudahan Rekreasi Taman Awam. Diperoleh dari http://jln.kpkt.gov.my/index.php/pages/view/69

[8] Jabatan Perancangan Bandar dan Desa Semenanjung Malaysia (JPBDSM) (2011), Garis Panduan Perancangan Reka Bentuk Sejagat (Universal Design). Diperoleh dari www.townplan.gov.my/publication.php.

[9] Kasim M., (2000). Proses dan Kaedah Reka Bentuk, Penerbit Universiti Teknologi Malaysia, Malaysia. pg. 11-27.

[10] Khorasani G. dan Zeyun L. (2014), A Study on Student's Satisfaction toward the Campus Transit System in Universiti Sains Malaysia, IMPACT: International Journal of Research in Business Managenment, Vol. 2, Isu 4, pg.7-16.

[11] Martin B. dan Hannington B., (2012). Universal Method of Design: 100 Ways to Research Complex Problems, Develop Innovative Ideas, and Design Effective Solutions, Rocksport Publisher, United State ofAmerica. 
[12] Meng, L. L., Nurwati, B., Lim, Y. M., Hanizam, A., Tiun, L. T. (2002). Universiti Sains Malaysia Main Campus Concept Plan: The Univerisity in the Garden - Policies and Guidelines, Universiti Sains Malaysia. (Draf Perancangan).

[13] Nor Azlina M. K. (2016) Memahami Rekabentuk Sejagat: Kajian Kes di Taman Permainan Mudah Akses, Taman Perbandaran Pulau Pinang. Proceeding Conference, $2^{\text {nd }}$ International Conference on Creative Media, Design \& Technology (REKA2016), ms. 722-730, School of The Art, Universiti Sains Malaysia, Pulau Pinang.

[14] Rotaris, L. dan Danielis R. (2014), The impact of transportation demand management policies on commuting to college facilities: A case study at the Universoty of Trieste, Italy, Journal of Transportation Research Part A, Elsevier Ltd, Vol. 67 (2014), pg.127-140.

[15] R. Hashim, S. Mohamad, S. Haron, F. Hassan. (2013), Assessment of Campus Bus Service Efficacy: An aplication toward green environment. Procedia - Social and Behavioral Sciences 105, pg. $294-303$.

[16] Story M. F., Mueller J. L., dan Mace R. L. (1998), The Universal Design File: Designing for People of All Age and Abilities. Design Research and Methods Journal, North Carolina State University: Center for UniversalDesign.

[17] Toor, W., dan Havlick S. W. (2004). Transportation and sustainable campus communities: Issues, examples, solutions. Washington, DC: IslandPress.

[18] Transit Cooperative Research Program (TCRP) (1996). Transit Cooperative Research Program Report 19: Guidelines for the Location and Design of Bus Stops (55-90). Washington, D.C. National Academy Press.

[19] TransLink (2007). Final Draft, Design Guidelines Report: Universally Accessible Bus Stop Design Guidelines (pg. 10-55). Vancouver: Greater Vancouver TransportationAunthority.

[20] Translink Transit Aunthority (2012). Public Transport Insfrastructure Manual: Bus Stop Planning and Design (pg. 9-35).Queensland.

[21] Tyler, N. (2002), Accessibility and the Bus System: From Concept to Practice, Thomas Telford Ltd, London.
[22] WMATA (2009). Guidelines: Design and Placement of Transit Stops (pg. 2-15). Washington: KFH Groups, Inc.

[23] Yin R. K. (2011). Qualitative Research from Start to Finish, New York: The Guilford Press.

[24] Zhang, F., Li Z., Zhao D., Wang Y., Wang W., dan Li Jianho, (2014), Influence of Various Types of Bus Stops on Traffic Operations of Bicycles, Vehicles, and Buses. Presentation at the 94st Annual Meeting of Transportation Research Board, Washington D.C.,2014. 